\title{
Roosting of Myotis myotis in a tree hollow in the Czech Republic (Chiroptera: Vespertilionidae)
}

\author{
Zdeněk TYLLER
}

Museum of the Valašsko Region, Horní nám. 2, CZ-775 01 Vsetín, Czech Republic; zdenek.tyller@centrum.cz

received on 17 November 2021

\begin{abstract}
Roosting of Myotis myotis in tree hollows is not common in the Czech Republic, and this phenomenon has not been a subject of a specific study. Here I report on a finding of one individual of $M$. myotis roosting in a natural tree hollow made by the black woodpecker in a beech forest near Voleč in the Pardubice Region. The bat was found during inspection of 35 cavities in a search for nesting birds. Such a survey has been conducted annually since 2009 and continues extensively till now with $1-4$ inspections per season from March to June.
\end{abstract}

Key words. Greater mouse-eared bat, hollow, tree, roost, inspection.

The greater mouse-eared bat, Myotis myotis (Borkhausen, 1797), is a common bat species in the whole southern and central Europe and belongs to common bats also in the Czech Republic. It feeds on the epigeic arthropods, namely large carabid beetles, often in forests, meadows and fields with short and sparse ground vegetation. As roosts, it uses natural and artificial caves and various spaces in buildings. During the reproduction season, the females form nursery colonies in attics, especially in churches and other large buildings, where they can be found in hundreds or even thousands of individuals. The males prefer to roost rather solitarily in various suitable cavities in buildings or underground spaces (HORÁČEK 1985, ANDĚRA \& HORÁČEK 2005). Less frequently, findings of Myotis myotis roosting in tree cavities have been also registered (SimON et al. 2004, ZAHN et al. 2006, RUDOLPH et al. 2009). Here, an evidence of a tree hollow roost of the greater mouse-eared bat is presented from the Czech Republic.

In the years 2009-2021, the author carried out an extensive survey of 35 tree hollows made mostly by the black woodpecker (Dryocopus martius) in the surroundings of Voleč (250 m a. s. 1., Pardubice Dist.); 1-4 inspections per year were made between the end of March till the end of June to document the bird species that use the particular hollows.

On 27 May 2019, the author found one individual of Myotis myotis roosting in one of 35 regularly inspected hollows (Fig. 1). The roost was in a beech tree, $8.8 \mathrm{~m}$ above ground; diameter of the tree at the hollow opening was $51.6 \mathrm{~cm}$, the size of the hollow opening was $7 \times 34 \mathrm{~cm}$ (the largest dimension was the height), the wall thickness of the wood at the opening was $8 \mathrm{~cm}$, and the inside diameter of the hollow was $20 \mathrm{~cm}$ (the distance between the opening and the top of the cavity was not measured). The hollow was used by birds just occasionally in ten consecutive years, probably because of the large opening size. The hollow was made originally by the green woodpecker (Picus viridis) in 2009 and this bird successfully nested there in the same year. The next year (2010), the black woodpecker enlarged the opening of the hollow and it was then used by the great tit (Parus major) for nesting. Since that, the hollow was used for nesting by the great tit in 2013, 2015, by the robin (Erithacus rubecula) in 2017, while in 2018 fungi 

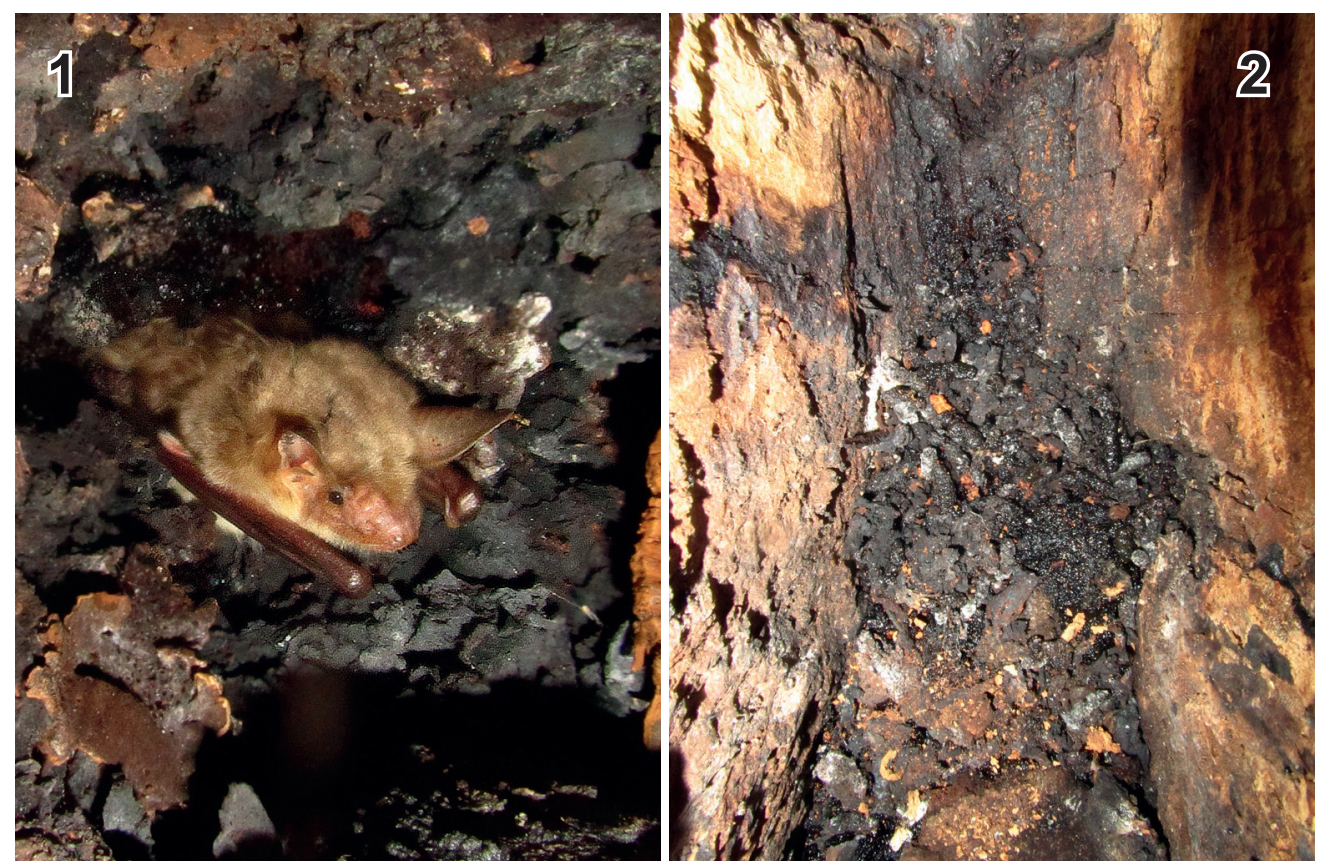

Figs. 1, 2. 1 - The greater mouse-eared bat (Myotis myotis) roosting in a beech tree hollow, found on 27 May 2019 (a forest near Voleč, eastern Bohemia). 2 - According to the amount of faeces in the tree hollow, the individual of the greater mouse-eared bat used the roost regularly.

filled up the whole space of the hollow. In the other years, there was no record of any bird or mammal species roosting in the hollow.

The thermal conditions of wood roosts in forests are relatively stable, as shown e.g., in the woodpecker hollows (KERTH et al. 2001). Therefore, natural tree hollows are used for day roosting by tree dwelling bats such as the common noctule (Nyctalus notula), lesser noctule (Nyctalus leisleri), brown long-eared bat (Plecotus auritus), Bechstein's bat (Myotis bechsteinii), and other species (HoráčEK 1986). In some years, the noctules were recorded in the surveyed tree hollows in the Voleč forest, but in the case of the greater mouse-eared bat, as a typical cave-dwelling species, the use of a tree hollow as a roost is rather unique. There are several such findings known from Germany (ZAHN et al. 2006, RUDOLPH et al. 2009) and Poland (LesiŃsKi et al. 2009). ZAHN et al. (2006) observed males of Myotis myotis roosting in tree hollows and bat boxes, RuDOLPH et al. (2009) found also females roosting in tree hollows. These female day roosts were in tree hollows made by a woodpecker (in three cases), one of the females used the same hollow in two consecutive years. They observed a pregnant female roosting in a woodpecker hollow for five days, however, the bat then returned to the colony for the following days (RUDOLPH et al. 2009.). According to the data by ZAHN et al. (2006), RUdOLPH et al. (2009) and LesIŃSKI et al. (2009), the roosting in tree hollows seems to be more common in males than in females of Myotis myotis; moreover, the selection of such roost type can be a consequence of foraging strategy of the particular individual and/or the current weather conditions. 
As foraging habitats, the greater mouse-eared bats prefer deciduous forests without dense ground vegetation to hunt ground beetles and this habitat type prevails in the Voleč beech forest. On the day of the bat finding, a frontal system crossed the region bringing heavy rain showers which continued the next day, so the bat individual might have profited from roosting at the area of foraging by shortening the flying time from its regular roost. However, in the tree roost, a large amount of bat faeces was present (Fig. 2), suggesting that the individual used the hollow more frequently, and not just occasionally as an emergency shelter from the rain.

\section{SOUHRN}

Úkryt netopýra velkého (Myotis myotis) v dutině stromu v České republice (Chiroptera: Vespertilionidae). Dne 27. května 2019 byl během kontrol 35 datlích dutin v bukovém porostu nedaleko obce Voleč, okres Pardubice, nalezen jedinec netopýra velkého (Myotis myotis) ukrytý v dutině (Fig. 1) vytvořené žlunou zelenou (Picus viridis). Podle množství trusu se jednalo o opakovaně využívaný úkryt (Fig. 2). Kontroly na dané lokalitě probíhají nepřetržitě od roku 2009, ale extenzivně, 1-4 kontroly ročně, od března do konce června za účelem sledování hnízdní biologie dutinových ptáků. Dutina byla ve výšce $8,8 \mathrm{~m}$, průměr stromu ve výšce dutiny byl $51,6 \mathrm{~cm}$, vletový otvor měl rozměry $7 \times 34 \mathrm{~cm}$, tloušt'ka stěny stromu u vletového otvoru byla $8 \mathrm{~cm}$ a vnitřní šířka dutiny $20 \mathrm{~cm}$. V roce 2009 dutinu vyhloubila žluna zelená a tentýž rok v ní vyvedla mlád’ata, následující rok (2010) datel černý (Dryocopus martius) zvětšil dutinu i vletový otvor, ale nezahnízdil. Pravděpodobně pro velmi velký vletový otvor a malou hloubku je tato dutina ptáky využíána méně často než datlí dutiny v sousedních stromech. Jako hnízdní dutinu si ji vybrali v letech 2013, 2015 a 2017 drobní pěvci a v roce 2018 byla celá vyplněna plodnicemi dřevokazných hub, v ostatních letech nebyla dutina využita ptáky ani savci. V dalších dutinách ve sledovaném porostu se nepravidelně objevují kolonie netopýra rezavého (Nyctalus noctula).

A c know ledgements

The author thanks Radek LUČAN for help with species determination and motivation to write this paper.

\section{REFERENCES}

AndĚra M. \& HoráčeK I., 2005: Poznáváme naše savce. 2. doplněné vydání [We Identify the Mammals of the Czech Republic]. Sobotales, Praha, 328 pp (in Czech).

HoráčEK I., 1985: Population ecology of Myotis myotis in Central Bohemia (Mammalia: Chiroptera). Acta Universitatis Carolinae - Biologica, 1980: 161-267.

HoráČEK I., 1986: Létajicí savci [Flying Mammals]. Academia, Praha, 156 pp (in Czech).

Kerth G., Weissmann K. \& König B., 2001: Day roost selection in female Bechstein's bats (Myotis bechsteinii): A field experiment to determine the influence of roost temperature. Oecologia, 126: 1-9.

LesiŃSki G., SkrzyPIEC-NowaK P., Janiak A. \& JAGNieSZCZAK Z., 2009: Phenology of bat occurrence in boxes in central Poland. Mammalia, 73: 33-37.

Rudolph B.-U., Liegl A. \& von Helversen O., 2009: Habitat selection and activity patterns in the greater mouse-eared bat Myotis myotis. Acta Chiropterologica, 11: 351-361.

Simon M., HüttendüGel S. \& SMit-VIERGUTZ J., 2004: Ecology and conversation of bats in villages and towns. Schriftenreihe für Landschaftspflege und Naturschutz, 77: 1-262.

Zahn A., Rottenwallner A. \& Güttinger R., 2006: Population density of the greater mouse-eared bat (Myotis myotis), local diet composition and availability of foraging habitats. Journal of Zoology, London, 269: 486-493. 